\title{
Genetic Variability of Maize (Zea mays L.) Genotypes on Some Yield and Yield Components at Haramaya, Eastern Ethiopia
}

\author{
Mekuannet Belay ${ }^{1, a, *}$, Degefa Gebissa ${ }^{1, b}$ \\ ${ }^{I}$ School of Plant Sciences (Agronomy), Haramaya University, Ethiopia \\ *Corresponding author \\ A R T I C L E I N F O A B S T R A C T \\ Research Article \\ Genetic improvement in components of economic importance along with maintaining a sufficient \\ amount of variability is always the desired objective in the any maize (Zea mays L.) breeding \\ program which will be handled under the conditions of Haramaya, Eastern Ethiopia. Therefore, an \\ experiment was conducted using (27) and (3) check/control varieties to determine the genetic \\ Received : 09/03/2020 \\ Accepted : 24/07/2020 \\ variability of maize genotypes at Haramaya, eastern Ethiopia. The study results revealed that \\ significantly the tallest plant heights for $(\mathrm{PH})$ were recorded from $(3)(170 \mathrm{~cm})$ and $(18)(167.5 \mathrm{~cm})$ \\ genotypes whereas the shortest PH were recorded from (13) $(117.5 \mathrm{~cm})$ and (23) genotypes $(120$ \\ $\mathrm{cm}$ ). Good plant aspects (PA) were obtained from genotype 12, 22 and 26 (PA-1.5) and poor PA \\ were attained from genotype 1 (PA-2.5). Besides, genetic and phenotypic variances were estimated \\ for seven components. The highest genotypic coefficients variation (GCV) and phenotypic \\ Keywords: \\ Maize (Zea mays L.) \\ coefficients of variation (PCV) were calculated from grain yield (GY - 23.39\%). Comparatively \\ Genotypes \\ Genetic variability \\ Yield and yield components \\ Haramaya \\ the higher GY were attained from the genotypes of 3,9 and 12. It can be concluded that almost all \\ components of the PCV are greater than the GCV. Superior selected genotypes are recommended \\ to the researchers /breeders to develop disease resistant and high yielder varieties to increase maize \\ production by farmers under Haramaya and other similar agroecologies.
}

\section{Introduction}

Maize (Zea mays $\mathrm{L}, 2 \mathrm{n}=2 \times=20$ ), a member of the grass family Gramineae (Poaceae), is one of the oldest cultivated crops. It is predominately cross-pollinated by wind, but self-pollination is also possible (Sleper and Poehlman, 2006). Maize is the most important crop worldwide and basic trade product recurring ingredient for millions of people in Sub-Saharan Africa (Nzuve et al., 2013). Among all cereals, maize is second to tef (Eragrostis tef Zucc.) in area coverage but first in productivity and total production (CSA, 2018). Similarly, maize is the second important cereal crop in area coverage and first in productivity following sorghum in east Hararghe (CSA, 2018).

In Ethiopia, maize is mainly produced for local consumption like raw material for a local drink, enjera, boiled grain (nifro), green cobs, and bread making.
Millions of people depend on maize as a staple food. Given its high demand for food grains and high yield per unit area, maize has been among the leading food grains selected to achieve food self-sufficiency in Ethiopia (Benti et al., 1993).

Among the various other characteristics, the GY in maize is the most important and complex quantitative character controlled by numerous gene (Varaprasad et al. 2016). Yield is a complex trait, is considerably influenced by different contributing yield components like the $\mathrm{EH}$, the PH and 1000- grain weight (Rahman et al. 1995). The GY is directly and positively associated with ear weight and ear circumference (Maia et al. 1997). Improvements in yield can be achieved by selection for the GY, 1000 grain weight, the PH and EH (Prodhan and Rai, 1997). The 
additive genetic variance component is the most important component of genetic variability for all components (Betran and Hallauer, 1996). All this information helps a plant breeder to ensure efficient cultivar selection and screening of available sources of maize germplasm (Varaprasad et al. 2016)

Maize is the global leading cereal in terms of annual production which is about 1040.21 million tons, followed by wheat (=Triticum spp.) with the production of 748.24 million tons and third in the area under cultivation among all cereal crops. In Ethiopia, maize ranks second after teff (Eragrostis teff) in area coverage and first in total production (Abate et al., 2015). In Ethiopia, maize grows under a wide range of environmental conditions from 500 to $2400 \mathrm{~m}$ asl. The mid-altitude, sub-humid agro-ecology is, however, the most important maize producing environment in the country (Kebede et al., 1993). Though Ethiopia compares favourably with the main maize producing country in Sub Saharan Africa, the country is yet to achieve its potential in terms of production because of the old varieties dominating the seed system in the country, many biotic and abiotic factors, lack of genetically diverse source materials and little success in developing high yielding hybrids and synthetic varieties for different agroecologies of the country (Abate et al., 2015).

Information on the nature and magnitude of variability and heritability in a population is one of the prerequisites for a successful breeding program in selecting genotypes with desirable traits (Dudly and Moll, 1969). Genetic improvement in components of economic importance along with maintaining a sufficient amount of variability is always the desired objective in maize breeding programs. To improve the genetic diversity of local germplasm, it is important to know the extent of already existing genetic variations in the material. The productivity and quality of maize are assured through initially evaluating, identifying, and properly selecting promising parental lines from available maize inbred lines. The national maize breeding program of Ethiopia also developed several maize inbred lines for use. However, little effort has been made; particularly in the mid-latitude area of the country to determine the variability of maize inbred lines considering their different morphological components. Therefore, this study aimed to determine the genetic variability of maize genotypes at Haramaya, Eastern Ethiopia with the maize (Zea mays L.) genotypes.

\section{Material and Methods}

\section{Description of the Experimental Site}

The experiment was conducted in the main cropping season under rainfed condition during the year 2018/19 at Raare, the research farm of Haramaya University. Geographically, Raare is located at $9^{\circ} 26^{\prime} \mathrm{N}$ latitude and $42^{\circ} 03^{\prime} \mathrm{E}$ longitude at an altitude of $1980 \mathrm{~m}$. a.s.l. The rain distribution of the area is bimodal. Total rainfall in growing season (April to October) was $786.6 \mathrm{~mm}$ and monthly average maximum and minimum temperature during growing seasons (April to October) was 24.5 and $13.4^{\circ} \mathrm{C}$ (Belay and Adare, 2020). The soil of the experimental site is a well-drained deep alluvial with a sub-soil stratified with sandy clay loam (Anteneh et al., 2015).

\section{Treatments and Experimental Design}

The experiment was comprised of (27) maize (Zea mays L.) genotypes and (3) standard checks provided from Ambo Agricultural Research Center. Treatments were laid out under alpha lattice design with (2) replications. The main plot size was $5.1 \mathrm{~m} \times 2.25 \mathrm{~m}\left(11.475 \mathrm{~m}^{2}\right)$ whereas the harvested net plot size was $5.1 \mathrm{~m} \times 1.5 \mathrm{~m}\left(7.65 \mathrm{~m}^{2}\right)$. Between and within row distances were $0.75 \mathrm{~m}$ and 0.25 $\mathrm{m}$, respectively, and these experimental materials were used (Table 1).

Table 1. Experimental materials used in the study

\begin{tabular}{cc|cc}
\hline G & Stock ID & G & Stock ID \\
\hline g1 & TH15104 & g17 & TH15244 \\
g2 & TH15162 & g18 & EBH161574 \\
g3 & TH15163 & g19 & TH15186 \\
g4 & TH15174 & g20 & TH15149 \\
g5 & TH15175 & g21 & TH15222 \\
g6 & TH15177 & g22 & EBH161576 \\
g7 & TH15180 & g23 & EBH151677 \\
g8 & TH15178 & g24 & EBH151678 \\
g9 & EBH161572 & g25 & EBH151679 \\
g10 & TH1551 & g26 & EBH1516780 \\
g11 & TH1550 & g27 & EBH151677 \\
g12 & TH15140 & g28 (AMH852Q) & Standard check \\
g13 & TH15143 & g29 (BHQPY545) & Standard check \\
g14 & TH15148 & g30 (AMH760Q) & Standard check \\
g15 & TH15149 & & \\
g16 & TH15152 & & \\
\hline
\end{tabular}

Source: Ambo Agricultural research center (2018), g=genotype

\section{Experimental Procedures}

The land was ploughed, disked and harrowed by a tractor. Field levelling was done manually before sowing. Then two seeds per hill were sown and then seeds covered with soil manually. Thinning to a single plant per each hill was done when seedlings produced three to four leaves to achieve the standard plant population. The full dose of $100 \mathrm{k}$ (NPS) and $1 / 287 \mathrm{~kg} \mathrm{~N}$ fertilizers were applied at sowing while the remaining $1 / 2 \mathrm{~N}$ was applied 50 days after sowing as a side dressing. Besides, other cultural practices were uniformly applied throughout the cropping season as recommended.

\section{Data Collection and Measurements}

Phenological parameters Days to $90 \%$ physiological maturity

It was recorded as a number of days from planting to the period when $90 \%$ of the plants' kernel formed a black layer at the point where it attached to the ear (CIMMYT,1985).

Yield and yield components

Plant height $(\mathrm{PH}-\mathrm{cm})$ : Ten randomly pre-tagged plants were taken from the net plot area and then their height was measured from the soil surface to the point where the tassel started to branch with a meter rod at physiological maturity (CIMMYT,1985).

Ear height $(E H-c m)$ : was recorded from ten randomly pre-tagged plants from each net plot area and measured their ear height from the ground level to the node bearing the top useful ear with a meter rod at physiological maturity (CIMMYT,1985). 
The number of ears per plant (NEPPL): It was randomly taken from ten pre-tagged plants in the net plot at harvest (CIMMYT,1985).

Plant aspect (PA): was scored using a 1-5 scale, where 1 indicates good (considering ear size, uniformity, disease infestation, husk cover, and so on) while 5 indicates poor genotype having undesirable ear components (CIMMYT,1985).

Ear aspect (EA): was recorded at harvest using 1 to 5 scales where 1 refers very good looking ear while 5 refers to poor ear with undesirable components (CIMMYT,1985).

Grain yield $\left(G Y-t h a^{-1}\right)$ : Field weight of all the harvested ears was weighted and converted into the GY using shelling percent of 80 percent. It was then determined in tons per hectare after adjusting the moisture content of 12.5 percent (CIMMYT,1985).

\section{Data Analysis}

All collected data were subjected to analysis by using GenStat statistical software $17^{\text {th }}$ (GenStat, 2014). For significant treatment effects, the mean separation was made using the least significant difference (Protected LSD) test at a 5\% level of significance (Gomez and Gomez, 1984).

\section{Estimation of Variance Components}

Variance components were estimated to identify genetic variability among inbred lines, genotypic $(\sigma 2 \mathrm{~g})$, phenotypic $(\sigma 2 \mathrm{p})$ and error variance $(\sigma 2 \mathrm{e})$, were calculated from expected mean squares of analysis of variance by adopting the formula suggested by Hallauer and Miranda (1988).

Where;

$$
\mathrm{GV}=\frac{(\mathrm{MSg}-\mathrm{MSe}) \times 100}{\mathrm{r}}
$$

$\mathrm{GV}=$ Genotypic variance $\sigma 2 \mathrm{~g}$

$\mathrm{MSg}=$ Mean square of genotype

$\mathrm{MSe}=$ Mean square of error

$\mathrm{r} \quad=$ Number of replications

Where;

$$
\mathrm{PV}=\sigma 2 \mathrm{e}+\sigma 2 \mathrm{~g}
$$

$\mathrm{PV}=$ Phenotypic variance $\sigma 2 \mathrm{p}$

$\sigma 2 \mathrm{e}=$ Error variance

$\sigma 2 \mathrm{~g}=$ Genotypic variance

$$
P C V=\frac{\sqrt{ } \sigma^{2} p \times 100}{\bar{x}}
$$

Where;

$$
\begin{aligned}
& \mathrm{PCV}=\text { Phenotypic coefficient analysis } \\
& \sigma 2 \mathrm{p}=\text { Phenotype variance } \\
& \overline{\mathrm{x}} \quad=\text { Mean of the PCV }
\end{aligned}
$$

GCV Values were categorized as low, moderate, and high values as indicated by Sivasubramanian and Menon (1973) as follows: $0-10 \%=$ low, $10-20 \%=$ Moderate and $>20 \%=$ high

$$
\mathrm{GCV}=\frac{\left(\sqrt{ } \sigma^{2} \mathrm{~g} \times 100\right.}{\overline{\mathrm{x}}}
$$

Where;

$\mathrm{GCV}=$ Genotypic coefficient analysis

$\sigma 2 \mathrm{~g}=$ Genotypic variance

$\overline{\mathrm{x}}=$ Mean of the PCV

\section{Results and Discussion}

\section{Phenological and Growth Parameters \\ Days to maturity (Days)}

Analysis of variance showed that statistical variation was not observed among genotypes due to days to maturity though the numerical difference was depicted among genotypes (Table 2). Genotypes 1, 13 and 14 were comparatively took fewer days $(174.5,174.5,174.0)$ to reach days to maturity as compared to other genotypes (Table 2). Similarly, Khan et al. (2017) found that genotype E-77 took the longest days (73.3) to reach 50\% silking whereas genotype MTM-2 took the shortest days to reach $50 \%$ silking. These results were supported by Hussain et al. (2005) reported genetic variation among different maize genotypes for days to $50 \%$ silking. They viewed that the differences in maturity among genotypes was due to genetic basis and reflection of weather pattern i.e. temperature, available soil moisture, etc.

Plant and ear height $(\mathrm{PH}-\mathrm{cm}$ and $\mathrm{EH}-\mathrm{cm})$

The PH was significantly influenced by the main effect of genotypes; however, the EH was not influenced due to the main effect of genotypes (Table 2). According to our results, the tallest $\mathrm{PH}$ values were recorded from 3 and 18 genotypes $(167.5$ and $170 \mathrm{~cm})$ whereas the shortest $\mathrm{PH}$ were taken from 13 and 23 genotypes $(117.5$ and $120 \mathrm{~cm}$ ) (Table 2). The variation found in PH trait could be due to genetic variations within the genotypes. This result is in line with the finding of Umakanth et al. (2000) who reported that similar results on genetic differences for the PH in maize genotypes. Nizam-ud-din et al. (2010) also reported a highly significant effect of genotypes on the $\mathrm{PH}$, but, Hassan et al. (2018) reported that the different $\mathrm{PH}$ values $(158.9-203.8 \mathrm{~cm})$ were recorded from various genotypes, it is a genetically inherited trait.

\section{Plant and Ear Aspects (The PA and EA)}

Analysis of variance depicted that the PA was significantly affected by the main effect of genotypes but the EA was not influenced (Table 2). Therefore, good the PA (1.5) were recorded from 12, 22 and 26 genotypes but poor plant aspect (2.5) was recorded from genotype 1. Generally, genotypes like 12, 22 and 26 are good the PA as compared to standard checks (Table 2)

\section{Yield Components and Yield of The Genotypes}

Number of ears per plant (NEPPL)

There was no statistical disparity obtained among tested genotypes due to the main effect of genotypes. However, numerical variations of the NEPPL were observed in the genotypes. A relatively the higher NEPPL were recorded from genotypes 5,12, 18, 20 and 30 (1.6,1.7,1.6,1.6 and 1.6 ) as compared to other genotypes including checks. The maximum NEPPL was recorded from genotype 12 (1.7) whereas the minimum NEPPL was obtained from the BHQPY 545 (0.9) (Table 2). This result was in line with Khan et al. (2017) who reported that different genotypes produced the different NEPPL values. 
Table 2. Mean values of the DM, PH and EH, NEPPL, PA and EA as well as the grain yield.

\begin{tabular}{|c|c|c|c|c|c|c|c|}
\hline Genotypes & $\mathrm{DM}$ & $\mathrm{PH}(\mathrm{cm})$ & $\mathrm{EH}(\mathrm{cm})$ & NEPPL & $\mathrm{PA}$ & EA & $\mathrm{GY}\left(\mathrm{t} \mathrm{ha}^{-1}\right)$ \\
\hline 13 & 174.5 & $117.5^{\mathrm{a}}$ & 50 & 1.50 & $2.25^{\mathrm{cd}}$ & 2.5 & $6.2^{\text {cdefg }}$ \\
\hline 23 & 176.0 & $120.0^{\mathrm{ab}}$ & 55 & 1.07 & $2.0^{\mathrm{bc}}$ & 2.5 & $3.5^{\mathrm{a}}$ \\
\hline 1 & 174.5 & $125.0^{\mathrm{abc}}$ & 52 & 0.92 & $2.5^{\mathrm{d}}$ & 2.25 & $4.7^{\mathrm{abcd}}$ \\
\hline 16 & 175.5 & $127.5^{\mathrm{abcd}}$ & 70 & 1.21 & $2.0^{\mathrm{bc}}$ & 2.0 & $6.3^{\text {cdefgh }}$ \\
\hline 2 & 175.0 & $130.0^{\text {abcde }}$ & 50 & 1.21 & $2.25^{\mathrm{cd}}$ & 2.25 & $4.1^{\mathrm{ab}}$ \\
\hline 25 & 177.0 & $130.0^{\text {abcde }}$ & 57.5 & 1.33 & $2.25^{\mathrm{cd}}$ & 2.5 & $4.9^{\text {abcdef }}$ \\
\hline 24 & 176.0 & $132.5^{\text {abcdef }}$ & 60 & 1.56 & $2.0^{\mathrm{bc}}$ & 2.25 & $4.8^{\mathrm{abcde}}$ \\
\hline 8 & 175.0 & $135.0^{\text {abcdefg }}$ & 60 & 1.13 & $2.0^{\mathrm{bc}}$ & 2.5 & $5.5^{\text {abcdef }}$ \\
\hline 6 & 175.0 & $137.5^{\text {abcdefgh }}$ & 50 & 1.42 & $2.25^{\mathrm{cd}}$ & 2.5 & $6.4^{\text {cdefgh }}$ \\
\hline 21 & 175.5 & $137.5^{\text {abcdefgh }}$ & 60 & 1.4 & $2.25^{\mathrm{cd}}$ & 2.5 & $4.6^{\mathrm{abcd}}$ \\
\hline 4 & 175.0 & $140.0^{\text {abcdefgh }}$ & 55 & 1.4 & $2.0^{\mathrm{bc}}$ & 2.0 & $8.9^{\mathrm{kl}}$ \\
\hline 7 & 176.0 & $140.0^{\text {abcdefgh }}$ & 62.5 & 1.15 & $2.0^{\mathrm{bc}}$ & 2.25 & $6.7^{\text {efghi }}$ \\
\hline 9 & 176.0 & $140.0^{\text {abcdefgh }}$ & 62.5 & 1.54 & $2.0^{\mathrm{bc}}$ & 2.0 & $9.9^{11}$ \\
\hline 10 & 177.0 & $140.0^{\text {abcdefgh }}$ & 65 & 1.52 & $2.0^{\mathrm{bc}}$ & 2.5 & $6.8^{\text {fghij }}$ \\
\hline 27 & 176.0 & $142.5^{\text {abcdefgh }}$ & 52.5 & 1.50 & $2.0^{\mathrm{bc}}$ & 2.25 & $5.7^{\text {bcdefg }}$ \\
\hline 20 & 175.0 & $147.5^{\text {abcdefgh }}$ & 62.5 & 1.60 & $2.0^{\mathrm{bc}}$ & 2.5 & $6.4^{\text {cdefgh }}$ \\
\hline 5 & 175.0 & $150.0^{\text {abcdefgh }}$ & 70 & 1.26 & $1.75^{\mathrm{ab}}$ & 2.25 & $5.5^{\text {abcdef }}$ \\
\hline 14 & 174.0 & $150.0^{\text {abcdefgh }}$ & 60 & 1.51 & $2.0^{\mathrm{bc}}$ & 2.0 & $5.9^{\text {bcdefg }}$ \\
\hline 29 & 175.5 & $152.5^{\text {bcdefgh }}$ & 60 & 0.97 & $2.0^{\mathrm{bc}}$ & 2.0 & $4.4^{\mathrm{abc}}$ \\
\hline 11 & 176.0 & $155.0^{\text {cdefgh }}$ & 65 & 1.18 & $2.0^{\mathrm{bc}}$ & 2.25 & $5.7^{\text {bcdefg }}$ \\
\hline 12 & 177.5 & $155.0^{\text {cdefgh }}$ & 75 & 1.70 & $1.5 \mathrm{a}$ & 2.0 & $8.9^{\mathrm{kl}}$ \\
\hline 22 & 175.0 & $155.0^{\text {cdefgh }}$ & 75 & 1.35 & $1.5 \mathrm{a}$ & 1.75 & $6.3^{\text {cdefgh }}$ \\
\hline 28 & 176.0 & $157.5^{\text {cdefgh }}$ & 77.5 & 1.18 & $2.0^{\mathrm{bc}}$ & 2.25 & $5.2^{\text {abcdef }}$ \\
\hline 19 & 175.0 & $160.0^{\text {defgh }}$ & 67.5 & 1.23 & $1.75^{\mathrm{ab}}$ & 2.0 & $6.6^{\text {defgh }}$ \\
\hline 30 & 176.5 & $160.0^{\text {defgh }}$ & 65 & 1.60 & $1.75^{\mathrm{ab}}$ & 2.5 & $7.5^{\text {ghijk }}$ \\
\hline 17 & 175.5 & $162.5^{\mathrm{efgh}}$ & 65 & 1.52 & $1.75^{\mathrm{ab}}$ & 2.25 & $8.8^{\mathrm{jkl}}$ \\
\hline 26 & 176.5 & $162.5^{\text {efgh }}$ & 72.5 & 1.24 & $1.5 \mathrm{a}$ & 2.0 & $6.1^{\text {bcdefg }}$ \\
\hline 15 & 176.5 & $165.0^{\text {fgh }}$ & 75 & 1.56 & $1.75^{\mathrm{ab}}$ & 2.5 & $8.7^{\mathrm{ijkl}}$ \\
\hline 18 & 176.0 & $167.5^{\mathrm{gh}}$ & 75 & 1.60 & $1.75^{\mathrm{ab}}$ & 2.0 & $8.2^{\text {hijkl }}$ \\
\hline 3 & 175.5 & $170.0^{\mathrm{h}}$ & 70 & 1.49 & $1.75^{\mathrm{ab}}$ & 2.25 & $9.3^{\mathrm{kl}}$ \\
\hline LSD (0.05) & NS & 27.3 & NS & NS & 0.22 & NS & 1.99 \\
\hline $\mathrm{CV}(\%)$ & 0.6 & 9.2 & 15.5 & 16.7 & 11.4 & 12.8 & 15.1 \\
\hline
\end{tabular}

Means in the column followed with the same letter(s) are not significantly different from each other at 5\% level of significance. DM= Days to Maturity, $\mathrm{PH}=$ Plant Height, EH= Ear Height, NEPPL= Number of ears per plant, PA= Plant Aspect, EA= Ear Aspect, LSD (0.05) = Least Significance Difference at $5 \%$ probability level; $\mathrm{CV}=$ Coefficient of Variation; NS = Non-significant

Grain yield $\left(G Y-t h a-^{l}\right)$

Analysis of variance showed that the GY was highly $(\mathrm{P}<0.01)$ significantly influenced by the main effect of genotypes. Therefore, the highest GY were obtained from genotype $3\left(9.3 \mathrm{t} \mathrm{ha-}-^{1}\right)$ and $9\left(9.9 \mathrm{t} \mathrm{ha}-{ }^{1}\right)$ whereas the lowest GY (3.5 $\mathrm{t} \mathrm{ha}^{1}$ ) was obtained from genotype 23 . Most of the genotypes gave higher GY as compared to the standard check (Table 2). The possible reason for the observed differences could be variation in their genetic makeup. This result is harmonized with Waqar et al. (2007) who reported that different maize genotypes gave different GY due to variation in their genetic yield potential. The results are in agreement with the findings of Drinic and Vancetovic (1994), who obtained similar results and further confirmed by Zhang et al. (2000). Similarly, Arwailayah et al. (2019) reported that there was highly significant genetic variability in the maize genotypes for GY.

\section{Estimation of Genetic Variability Parameters}

\section{Phenotypic and genotypic variance (PCV and GCV)}

Genetic and phenotypic variances were estimated for seven components. The GCV for different components was ranged from $0.24 \%$ for days to maturity to $23.39 \%$ for the
NEPPL (Table 3). As the number of ears is determined by multiple minor genes whose effects are sensitive to environmental and experimental variations. In fact, a high coefficient of variation is expected. The trend in the PCV is not consistent with the GCV. However, the PCV for various components ranged from $0.6 \%$ for the days to maturity to $28.4 \%$ for the GY. Therefore, the lowest GCV (0.24) and PCV (0.6) were found from days to maturity (Table 3).

According to Deshmukh et al (1986), the highest GCV $(23.39 \%)$ and PCV $(28.4 \%)$ were taken from the GY. The PCV and GCV values greater than $20 \%$ is considered as high, whereas values less than $10 \%$ regarded as to be low and values $10 \%$ and $20 \%$ to be medium (Deshmukh et al. 1986). Based on this scale, the components like the NEPPL $(23.5 \%)$ and the GY (28.4\%) showed the high PCV. This result was in line with Hussain et al. (2005) who reported that high the PCV (42.0) was recorded from the GY. However, the PH $(11.9 \%)$, the EH $(17.1 \%)$, the PA $(16.4 \%)$ and the EA $(14.3 \%)$ showed medium PCV while only days to maturity showed low PCV. On the other hand, high GCV value was obtained from the GY $(23.39 \%)$ where components like days to maturity $(0.24 \%)$, the $\mathrm{PH}$ $(7.63 \%)$, the $\mathrm{EH}(7.11 \%)$, the PA $(8.72 \%)$ and the EA 
$(4.46 \%)$ were grouped under low GCV. Jilo et al. (2018) reported that the high GCV and PCV were found from the $\mathrm{GY}$, anthesis and silking interval, ear diameter, the $\mathrm{EH}$ and the PA suggesting that these components are under the influence of genetic control. The remaining components such as the number of kernel rows per ears (10.36), leaf length (8.56), days to $50 \%$ anthesis (5.21), days to $50 \%$ silking (4.83) and days to maturity (2.67) showed a low
PCV. Similarly, Kumar et al. (2014) and Nzuve et al. (2014) also reported the highest GCV and PCV for the PH, the EH, 1000 grain weight and the kernel number per row. The result showed that almost all components of the PCV are greater than the GCV. This indicated that all components were affected by environmental factors. Similar results were reported by Arunkumar et al. (2013) and Chavan et al. (2010).

Table 3. Genotypic $\left(\sigma^{2} \mathrm{~g}\right)$ and phenotypic $\left(\sigma^{2} \mathrm{p}\right)$ variations, gvc $(\%)$, pvc $(\%)$ and broad sense heritability $\left(\mathrm{h}^{2}-\%\right)$ in the genotypes

\begin{tabular}{l|ccccc}
\hline \multicolumn{1}{c|}{ Traits } & $\sigma_{\mathrm{g}}^{2}$ & $\sigma_{\mathrm{p}}^{2}$ & $\mathrm{GVC}(\%)$ & $\mathrm{PVC}(\%)$ & $\mathrm{H}^{2}(\%)$ \\
\hline Days to maturity & 0.19 & 1.1 & 0.24 & 0.6 & 16.5 \\
Plant height & 123.88 & 301.5 & 7.63 & 11.9 & 41.1 \\
Ear height & 20.46 & 116.7 & 7.11 & 17.1 & 17.5 \\
Plant aspect & 0.03 & 0.1 & 8.72 & 16.4 & 40.1 \\
Ear aspect & 0.01 & 0.1 & 4.46 & 14.3 & 9.5 \\
Number of ears per plant & 0.02 & 0.1 & 10.28 & 23.5 & 23.9 \\
Grain yield & 2.34 & 3.3 & 23.39 & 28.4 & 71.2 \\
\hline
\end{tabular}

\section{Conclusion}

In Ethiopia, the maize plant is mainly produced for local consumption, and grown under a wide range of environmental conditions. In this study, totally (30) maize genotypes were used. Some genotypes were not influenced due to genotype effect whereas other components were significantly affected. Therefore, among tested genotypes, the tallest PH was obtained from genotype $3(=170 \mathrm{~cm})$ and the good PA were obtained from genotypes 12, 22 and 26 with checks. Likewise, comparatively the higher GY values were taken from the genotypes 3,9 and 12 (=Values?). The PH (11.9\%), the EH (17.1\%), the PA $(16.4 \%)$ and the EA (14.3\%) showed medium PCV while only days to maturity showed the low PCV. The high GCV value was obtained from the GY (23.39\%) where components like days to maturity $(0.24 \%)$, the PH $(7.63 \%)$, the $\mathrm{EH}(7.11 \%)$, the PA $(8.72 \%)$ and the EA $(4.46 \%)$ were grouped under the low GCV. In the light of these findings, it can be concluded that almost all components of the PCV are greater than the GCV and different genotypes have various genetic yield potential and other components. Therefore, the superior selected genotypes are recommended to breeders to develop new maize varieties to maximize maize production under Haramaya and other similar agro-ecologies.

\section{Acknowledgments}

We would like to acknowledge the Haramaya University and Ethiopian Institute of Agriculture Research (EIAR) for their financial support.

\section{References}

Abate T, Bekele S, Abebe M, Dagne W, Yilma K, Kindie T, Menale K, Gezahegn B, Berhanu T, Tolera K. 2015. Factors that transformed maize productivity in Ethiopia. Food Security 7(5): 965-981.

Anteneh A, Eyasu M, Daniel M. 2015. Agronomic efficiency of $\mathrm{N}$ of common bean (Phaseolus vulgaris L.) in some representative soils of Eastern Ethiopia. Cogent Food \&Agriculture, $1: 1-15$.
Arunkumar R, Josephs EB, Williamson RJ, Wright SI. 2013. Pollen-specific, but not sperm-specific, genes show stronger purifying selection and higher rates of positive selection than sporophytic genes in Capsella grandiflora. Mol. Biol. Evol. 30(11): 2475-2486.

Benti T, Tasew G, Mosisa W, Yigzaw D, Kebede M,Gezahegne B. 1993. Genetic improvement of maize in Ethiopia: A review. pp.13 22. In: Benti Tolessa and J.K. Ransom (eds.). Proc. of the First National Maize Workshop of Ethiopia, May 5-7, 1992, Addis Ababa, Ethiopia.

Betran FJ, Hallauer AR. 1996. Characterization of interpopulation genetic variability in three hybrid maize populations. J. Heredity. 87(4): 319-328.

Chavan SK, Mahajan RC, Fatak SU. 2010. Genetic variability studies in sorghum. Karnataka J. Agric. Sci., 23(2): 322-323.

CIMMYT. 1985. Managing Trials and Reporting Data for CIMMYT's International Maize Testing Program, Mexico, D.F. Pp. 1-20.

CSA. 2018. Central Statistical Agency, Agricultural sample survey reports on area and production of major crops, Vol. 1, 2017, Addis Ababa, Ethiopia, pp. 10-50.

Deshmukh SNN, Basu MS, Reddy PS. 1986. Genetic variability, character association and path coefficients of quantitative components in virginia bunch varieties of groundnut. Indian J. Agric. Sci., 56: 816 - 821 .

Drinic G, Vancetovic J. 1994. Genetic variability for yield in top cross populations of maize (Zea mays L.). Issue 1,Vol. 1 End page 47.

Dudly JW, Moll RH. 1969. Interpretation and use of estimates of heritability and genetic variance in plant breeding. Crop Sci., 9: 257-267.

Gen Stat. 2012. GenStat procedure library release. 15th edition. VSN International Ltd.

Gomez KA, Gomez AA. 1984. Statistical Procedures for Agricultural Research ( $2^{\text {nd }}$ ed). John Wiley and Sons. New York, USA. 680p

Hallauer AR, Miranda JB. 1988. Quantitative genetics in maize breeding. 2nd ed. Iowa state Universality Press. Pp. 1-680.

Hassan AA, Mehedi H, Azad MA, Hasanuzzaman Md. 2018. Genetic variability and diversity studies in maize (Zea mays L.) inbred lines. IOSR J. Agric. and Veter. Sci., (IOSRJAVS), Vol. 11, pp. 69-76.

Hussain N, Hayat K, Zubair M, Aziz A, Zaman Q. 2005. Adoptability of maize varieties to D. I. Khan ecology. Indus J. Plant Sci., 4(2): 191-195. 
Jilo T, Tulu L, Birhan T, Beksisa L. 2018. Genetic variability, heritability and genetic advance of maize (Zea mays L.) inbred lines for yield and yield-related components in southwestern Ethiopia. J. Plant Breed. Crop Sci., 10(10): 281-289

Kebede M, Gezahegne B, Benti T, Mossisa W, Yigzaw D, Assefa A. 1993. Maize production trends and research in Ethiopia. Proc. the First National Maize Workshop of Ethiopia. AddisAbaba, Ethiopia pp. 142-154.

Khan B, Nausherwan NN, Maqsood Q, Mudassar A, Muhammad H, Anisa I, Hussain A, Israr A, Kinza K, Maleeha A. 2017. Genetic variability in different maize (Zea mays L.) genotypes for comparative yield performance under local conditions of Rawalakot, Azad Jammu and Kashmir. Int. J. Biosci., Vol. 11, pp. 102-107.

Kumar GP, Reddy VN, Kumar SS, Rao PV. 2014. Genetic Variability, heritability and genetic advance studies in newly developed maize genotypes (Zea mays L.). In. J. Pure and Applied Biosci., 2(1): 272-275.

Maia JDG, Osuna JA, Tozetti AD. 1997. Recurrent selection and path coefficient analysis in maize (Zea mays L.) $\mathrm{S}_{1}$ progenies. Ecossistema. Caixa Postal. Jales, SP, Brazil. 22: 68-73

Belay M, Adare K. 2020. Response of Growth, Yield Components and Yield of Hybrid Maize (Zea mays L.) Varieties to Newly Introduced Blended NPS and N fertilizer rates at Haramaya, Eastern Ethiopia, Cogent Food \& Agriculture, 6:1,1771115:1-15

Nizam-uddin, Qasim M, Hussain M. 2010. Comparative study of agronomic parameters in synthetic maize varieties. J. Agric. Res., Vol. 48: 53-57.

Nzuve F, Githiri S, Mukunya DM, Gethi J. 2013. Analysis of genotype $\mathrm{x}$ environment interaction for grain yield in maize hybrids. J. Agric. Sci., 5(11):75-84.
Nzuve F, Githri S, Mukunya DM, Gethi J. 2014. Genetic variability and Correlation studies of grain yield and related agronomic components in maize. J. Agric. Sci., 6(9):166-176.

Prodhan HS, Rai R. 1997. Genetic variability in popcorn. Indian Agric. 41(4): 287-290.

Rahman MM, Ali MR, Islam MS, Sultan MK, Mitra B. 1995. Correlation and path coefficient studies in maize (Zea mays L.) composites. Bangladesh J. Sci. and Indust. Res. 30(1): 8792.

Sivasubramanian S, Menon M. 1973. Heterosis and inbreeding depression in rice. Madras Agric. J. 60: 1139-1140.

Sleper DA, Poehlman JM. 2006. Breeding of field crops (No. Ed. 5). Blackwell publishing, ISBN 1-56022-278-6, pp. 424.

Arwailayah TF, Wali MC, Emmanuel AA, Williams SK, Cheelo P. 2019. Genetic Variability and Divergence Studies in Maize (Zea mays L.). Environment Canada's Agriculture. 5 (6): 284-290.

Umakanth AV, Satyanarayana E, Nagesh MVK. 2000. Correlation and heritability studies in Ashwini maize composite. Annals of Agric. Res. 21(3): 328-330.

Varaprasad BV, Shivani D, Anil Kumar G. 2016. Genetic Analysis of Pooled Variation and Heritability in Maize Inbred Lines and Hybrids, International Journal of Research and Scientific Innovation (IJRSI) |Volume III, Issue VIII, August 2016, ISSN 2321-2705:77-80.

Waqar A, Rehman H, Ahmad K, Iqbal M, Ahmad K. 2007. Genetic variability among maize hybrids for yield and yield components. Sarhad J. Agric. Vol. 23: 75-80.

Zhang, X.F., Y. Jin, Y.L. Zhang, H.Z. Chang and Z.H. Wang. 2000. Genetic analysis of the quantitative components of the improved maize population of NEAU-2. Scientia Agric. Sinica. 33: Suppl. 105-112. 